https://doi.org/10.18485/iipe_60nam.2021.ch14

\title{
EGYPT AND THE NON-ALIGNED MOVEMENT
}

\author{
Ezzat SAAD ${ }^{1}$
}

\begin{abstract}
The Non-Aligned Movement (NAM) is the second-largest international grouping after the United Nations. Today, the NAM represents more than $60 \%$ of the latter's members and more than half of the world's population. Thus, it forms a large voting bloc, especially as it includes many major powers in its membership, which play important roles in the regional and international arenas, and their decisions are taken into account in international issues. Therefore, the movement should take advantage of this great weight in favour of establishing justice and peace in the world, and there is no doubt that its role in this regard has begun to grow in light of the decisive developments and changes that are taking place in the international arena over the past few years.

On the other hand, Egypt is one of the founding countries of the NonAligned Movement; it has a recognized vital role in founding, building, and developing the movement. Egypt has attempted - in cooperation with its partners - to keep the survival and continuity of the movement, using the latter's regional and international weight, as it represents the most important framework as well as the broader scope to coordinate the positions of developing countries on various political, economic and social issues of the international system. Egypt also had a clear contribution to transforming ideas related to non-alignment into a tangible reality at the inception of the movement, and it also hosted its second summit in 1964 and the fifteenth high summit in Sharm El-Sheikh in 2009.
\end{abstract}

Key words: Egypt, the Non-Aligned Movement, developing countries, aims, vision.

${ }^{1}$ Director, Egyptian Council for Foreign Affairs, Cairo, Egypt. E-mail: ecfa.egypt.2020@gmail.com 


\section{The Non-Aligned Movement: Aims and Aspirations}

It is well known that the Non-Aligned Movement (NAM) was born out of the womb of the post-World War II era and as a consequence of an ideological conflict between the East and West Camps. During that period, hundreds of millions of people got rid of colonialism and the leaders of newly independent States feared their countries would be the scene of competition between Socialism and Capitalism. Thus, they created a number of ideas with the purpose of steering away from a potential conflict zone. Therefore, the idea of "Non-alignment" was first conceived at the 1955 Bandung Conference of Afro-Asian Solidarity in Indonesia. And in 1961, the Non-Aligned Movement was established thanks to the efforts of such leaders as Gamal Abdel Nasser (Egypt), Jawaharlal Nehru (India), Josip Broz Tito (Yugoslavia) and Ahmed Sukarno (Indonesia). The preparatory meeting for the First NAM Summit Conference held in Cairo from 5-12 June 1961 had laid down the goals of the policy of non-alignment, which were adopted as criteria for membership. These came as follows:

- The country should have adopted an independent policy based on the coexistence of States with different political and social systems and nonalignment or should be showing a trend in favour of such a policy;

- The country concerned should consistently support the Movements for national independence;

- The country should not be a member of a multilateral military alliance concluded in the context of Great Power conflicts;

- If a country has a bilateral military agreement with a Great Power or is a member of a regional defence pact, the agreement or pact should not be deliberately concluded in the context of Great Power conflicts, and

- If it has conceded military bases to a Foreign Power, the concession should not have been made in the context of Great Power conflicts.

However, the idea of non-alignment did not signify that a state ought to remain passive or even neutral in international politics. On the contrary, since the founding of the Non-Aligned Movement, its stated aim has been to give a voice to developing countries and encourage their concerted action in world affairs. The NAM has sought to "create an independent path in world politics that would not result in member States becoming pawns in the struggles between the major powers". It identifies the right of independent judgment, the struggle against imperialism and neocolonialism, and the use of moderation in relations with all big powers as the three basic elements that have influenced its approach. On the other 
hand, The Founding Principles of the Non-Aligned Movement had come to reinforce the above goals and criteria. These principles asserted on respecting fundamental human rights and the purposes and principles of the Charter of the United Nations; respecting the sovereignty and territorial integrity of all nations; recognition of the equality of all races and the equality of all nations, large and small; abstention from intervention or interference in the internal affairs of another country; refraining from acts or threats of aggression or the use of force against the territorial integrity or political independence of any country; settlement of all international disputes by peaceful means, such as negotiation, conciliation, arbitration, or judicial settlement, and other peaceful means of the party owns choice, in conformity with the Charter of the United Nations; and promotion of mutual interests and co-operation.

It is worth mentioning that the NAM, based on its constructive role in supporting developing nations, is the parent-organisation of various groupings of these developing nations, which seek to defend their interests in the competition between rich and poor and North and South. And to cull the fruits of South-South cooperation, it is essential for these nations to promote solidarity and coordination between those groupings. Duality and conflict of role and interests should be avoided to prevent a weakened negotiating position facing advanced nations which hold control of international financial and monetary institutions. By the way, the collaborative efforts among the member States of the NAM are conducted through an ambassadorial-level body at the United Nations' Headquarter in New York, which reviews and facilitates activities between the working groups, contact groups, task forces, and committees, in order to strengthen the overall coordination and cooperation among the NAM States. Actually, with the collapse of the Soviet Union and the end of the Cold War in the early 1990s, great controversy was held both inside and outside the Movement over its present and future role. But, taking into account the accelerated and radical changes of the world order since the 1990s, the NAM is entitled to play a great role in the international arena as it will follow below.

\section{Egypt's Vision on the NAM}

Egypt played a major role in the formation of the Non-Aligned Movement, at the hands of the Egyptian charismatic revolutionist leader Gamal Abdel Nasser, with his Asian and African partners. Egypt pursued developing the idea of establishing the NAM from the very beginning till it 
became a significant real entity at the 1955 Bandung Conference. President Nasser's vision called for a collective union consisting of developing nations that could freely work on their own problems, analysing them and finding solutions. Nasser advocated non-interference from the two power blocs when it came to the foreign policy of the newly independent states of Asia and Africa. His vision and influence also spread to the rest of the Arab world as his adoption of a non-aligned policy encouraged other Arab nations to become neutral in their approach to diplomacy regarding the Western and Eastern blocs. Increasingly after 1955, Nasser and the Egyptian press emphasized the ideas of neutralism or non-aligned with either of the worldpower blocs as the foreign policy most suitable for the newly liberated colonies of Africa and Asia. Subsequently, Cairo has hosted the preparatory meeting for the first NAM Summit of Belgrade from 5-12 June 1961, and then the Second Summit in October 1964, attended by forty-seven countries. Ruling Egypt from 1954 until his death in 1970, Nasser remains a symbol of dignity, anti-Zionism, decolonisation, pan-Arabism, and above all social justice for many. The sentiment expressed by President Nasser and his vision for the solidarity of developing countries is relevant even today.

In this context, it was clear that Egypt believed in the ability of NAM to be the most important and broader framework for coordinating stances of the developing countries regarding the various international political, economic, and social issues, including the agenda of the United Nations along with supporting collective action in the face of unilateral policies, which constitute a challenge facing the third world countries. This has already become the main characteristic of the role of the NAM, worldly. In 2009, the Egyptian Red Sea resort Sharm el-Sheikh hosted the Fifteenth Summit of NAM, where 118 countries participated in the activities of the movement, including 55 heads of state, with some other countries having the observer status. The final document of that Summit reiterated the necessity to attain the goals of the NAM, including achieving justice and equality between the two halves of the world (North \& South); solving the international disputes peacefully; keeping stability and security of the States and promoting multilateralism as the core principle of negotiations in the area of disarmament and non-proliferation, etc. There is no doubt that the significance of those issues has increased in the last few years, taking into account the rapid international changes and challenges, especially in light of the Covid-19 pandemic. In the recent Summit of May 2020, the member states are set to coordinate their efforts to curb the spread of the novel virus and discuss ways to deal with the virus from the health, economic and social aspects. The Egyptian President Abdel Fattah El-Sisi highlighted the need 
for international cooperation and solidarity to immediately respond to the coronavirus crisis. He also called for supporting the economies of developing countries and curbing the impact of the crisis on food security. On the other hand, the Egyptian Foreign Minister Sameh Shoukry recalled, at the NAM virtual meeting held on 10 October 2020 on the sidelines of the $75^{\text {th }}$ session of the United Nations General Assembly, for establishing a Middle East Zone Free of Nuclear Weapons and Other Weapons of Mass Destruction, applying the internet governance, and preserving the cyber security. He also confirmed Egypt's firm support for the political solutions to the conflicts in Libya, Syria, and Yemen, besides finding a just and comprehensive solution to the Palestinian issue in accordance with the international resolutions to end the occupation and establish a Palestinian independent state with East Jerusalem as its capital. At the end of the meeting, the participants adopted a political declaration regarding the NAM priorities which included addressing the economic and social repercussions of the Covid-19 pandemic, combating terrorism, and strengthening efforts to maintain international peace and security. Additionally, the meeting praised Egypt's initiative of "Cairo Road Map for Enhancing Peacekeeping Operations" in supporting the balanced implementation in the UN peacekeeping system. Actually, Egypt is very much interested in the movement and the need to preserve it for the NAM's international positive influence and continues to be an important active member within the NAM till the present day. The Non-Aligned Movement, in light of its rich cultural, geographical and political weights, constitutes the basis on which Egypt depends for supporting the NAM's objectives and mechanisms, currently and in the future, through intensifying joint efforts with many international parties, in order to make the movement more efficient in dealing with major political, economic and cultural changes in the global arena, particularly after the positive shifting from 25 nations participating at the first NAM Summit in 1961 to a large entity currently comprising 120 members from Africa, Asia, Europe, and Latin America.

\section{Urgent Need in a Changing World}

It has already been pointed out that a great controversy has been raised both inside and outside the Non-Aligned Movement since the 1990s, specifically after the collapse of the Soviet Union, about the legitimacy and the return of the continuation of the movement. Two completely different views evolved. The first maintained that the NAM became obsolete, particularly as its raison d'être was actually no more existent. The Cold War 
had ended and several changes took place with regard to some of its founding members. Yugoslavia, for instance, disintegrated into several smaller states. Other countries entered strategic alliances with the US. Another view is that the Movement had more justifications to continue than to disappear. The NAM secured many achievements in the past. Numerous challenges arose, which called for revitalizing its role: e.g., the need to defuse tensions and solve international and regional problems which have lasted for a long time. The NAM could also help prevent developed countries from hegemonizing over developing ones, and from interfering in their affairs using such pretexts as the fight against terrorism, humanitarian intervention and the spread of democracy. The Movement seeks to achieve global economic reform, narrow the widening economic gap between North and South, end poverty and hunger and promote dialogue and coexistence between peoples and cultures. In this context, it is reasonable to stick to the side confirming the urgent existence of the NAM in order to address recent international changes. The NAM has already promoted international cooperation between its members and managed to attract many of them through its just, moderate and legitimate claims and visions. The end of the Cold War and the bipolar system did not succeed in putting an end to the imbalances the world was suffering from at the time, as previously mentioned. Hence, the continuation of the NAM and its role in the international system are justified, particularly in light of its enormous capabilities on all political, economic, cultural and geographical levels. Therefore, there is imperative to reaffirm the principles on which the NonAligned Movement was established, particularly in regard to noninterference in the internal affairs of States, respect of their sovereignty, stability and independence of their decisions, besides the inadequacy of the national sovereignty and territorial integrity. More and above, internal affairs became a pretext for practising hegemony on others. Additionally, in light of the growing tensions between the United States and China, alongside Russia, the Non-Aligned Movement should keep declaring its members' neutral positions with clarity and courage to preserve their interests, which undoubtedly are affected by the strained relations of major powers in one way or another. All these massive challenges require maintaining the NAM, as well as intensifying efforts for rebuilding and promoting its capabilities, in order to defend a peaceful, cooperative and multilateral international equitable system. Hence, the NAM should reassess its identity and purpose in the post-Covid-19 era, exploiting its unique capabilities. A reformation program should be introduced in order to be more effective on the basis of common interests and mutual benefits. The movement should follow its long 
speeches and documents by positive practical actions. In addition, according to his contribution to Bandung Journal of the Global South, S. Keethaponcalan proposes to upgrade the entity from a movement to an international organisation in order to give it the official and organisational lustre within which it can operate, alongside the rest of the international organisations, in an optimal and efficient manner. It is preferable to consider the idea of drafting a formal constitution, establishing a permanent secretariat, as well as convening annually due to the great changes taking place and the large number of its members who are affected by those changes.

\section{References}

Final Document of the $15^{\text {th }}$ Summit Conference of Heads of State or Government of the Non-Aligned Movement, Sharm el Sheikh, Egypt, $11^{\text {th }}$ to $16^{\text {th }}$ of July 2009 (NAM2009/FD/Doc.1), retrieved from, http://cns.miis.edu/nam/documents/Official_Document/15SummitFinal-_Compiled.pdf. 23.03.2021.

S. I. Keethaponcalan. Reshaping the Non-Aligned Movement: challenges and vision. Bandung Journal of the Global South, October 2016, retrieved from, http:/ / dcac.du.ac.in/documents/E-Resource/2020/Metrial/427 MukeshBagoria1.pdf. 23.03.2021.

André Munro, "Non-Aligned Movement", retrieved from, https:// www.britannica.com/topic/Non-Aligned-Movement.

"Non-Aligned Movement (NAM)". 20 July 2009, retrieved from, https://www.sis.gov.eg/Story/335/Non-Aligned-Movement-(NAM)? lang=en-us. 1.02.2020.

"Non-Aligned Movement (NAM): Egypt", retrieved from, https://byjus. com/free-ias-prep/egypt-non-aligned-movement-1955-1973/.01.01.2020.

“Non-Aligned Movement (NAM)". 25 February 2021, retrieved from, https:// www.nti.org/learn/treaties-and-regimes/non-alignedmovement-nam/. 26.02.2021.

"NAM Summit: Sisi urges global cooperation amid coronavirus crisis". 4 May 2020, retrieved from, https://www.egypttoday.com/Article/ 1/85420/NAM-Summit-Sisi-urges-global-cooperation-amidcoronavirus-crisis. 04.05.20202.

"Egypt participates in Non-Aligned Movement virtual meeting". 10 October 2020, retrieved from, https:/ /www.egypttoday.com/Article/1/92908/ Egypt-participates-in-Non-Aligned-Movement-virtual-meeting. 20.10.2020 